\title{
PENDIDIKAN AKHLAK BERWAWASAN INTEGRATIF INKLUSIF
}

\author{
M. Syafiqurrohman \\ Email: syafiqurrohmanlu@gmail.com.id \\ (Institut Agama Islam Negeri (IAIN) Purwokerto)
}

\begin{abstract}
Abstrak
Pendidikan akhlak berwawasan integratif-inklusif dapat dimaknai sebagai suatu rumusan proses pendidikan akhlak yang dilakukan secara luas dan holistik. Materi pendidikan akhlak dapat bersinergi dengan seluruh mata pelajaran, dapat bersinergi dengan budaya sekolah, kegiatan estrakulikuler serta bersinergi dengan komunitas. Dikatakan struktur keilmuan integratif bukan berarti antara berbagai ilmu tersebut dilebur menjadi satu bentuk ilmu yang identik, melainkan karakter, corak, dan hakikat antara ilmu tersebut terpadu dalam kesatuan dimensi material spiritual, akal-wahyu, ilmu итит ilmu agama, jasmani-ruhani, dan dunia akhirat.
\end{abstract}

\section{Kata Kunci: Pendidikan Akhlak, Berwawasan Integratif-Inklusif}

\section{A. Pendahuluan}

Fenomena pendidikan nasional yang selama ini hanya mengakomodasi pendidikan akhlak dalam pendidikan agama Islam menjadikan kajian materi yang bersikap menyendiri dan kurang berinteraksi dengan kegiatan-kegiatan pendidikan lainnya. Sebagai dampaknya, upanya realisasi nilai-nilai akhlak luhur pada diri peserta didik sangat terbatas dan sempit. Dengan demikian, nampak bahwa pendidikan akhlak dalam sistem pendidikan nasional belum mendapat perhatian yang cukup, sehingga tujuan pendidikan akhlak sebagai pembentuk manusia yang senantiasa mengikatkan diri kepada norma-norma dan nilai-nilai luhur semakin sulit tercapai.

Peran penting pendidikan akhlak sebagai jati diri umat islam yang menfokuskan pada tata cara berprilaku luhur seharusnya dapat bersinergi dalam seluhur komponen pendidikan secara integratif dan inklusif. Menghilangkan sekat dikotomi antara mata pelajaran serta memperhatikan perbedaan individu terutama dalam hal kemampuan dan kecepatan belajar seharunya menjadi ruh dalam rangkaian proses pendidikan akhlak. Sehingga tugas pendidikan akhlak dalam mengaktualisasikan akhlak luhur pada diri peserta didik dapat dilakukan secara holistik tanpa terbatasi sekat mata pelajaran dan kondisi peserta didik.

Karya tulis ini akan mengkaji lebih dalam tentang konsep integrasi materi akhlak dalam mata pelajaran umum. Hal tersebut sebagai upaya menjadikan materi pendidikan akhlak sebagai materi pembelajaran yang dinamis dan holistik sehingga pokok kajian pendidikan akhlak dapat bersinergi dalam seluruh rangkaian pembelajaran.

\section{B. Pembahasan}

\section{Materi Pendidikan Akhlak}

Islam sangat memperhatikan pendidkan akhlak dan mengangapnya sebagai sesuatu yang sangat penting dan istimewa. Al-Qur'an sebagai kitab petunjuk didalamnya terdapat keterangan berkisar 1500 ayat yang berbicara tentang akhlak dua setengah kali lebih banyak dari ayat-ayat tentang hukum baik yang teoritis maupun yang praktis. Belum terhitung hadis-hadis Nabi, baik perkataan maupun 
perbuatan, yang memberikan pedoman akhlak yang mulia dalam seluruh aspek kehidupan. Secara etimologi, akhlak berasal bahasa arab yang merupakan bentuk jamak dari kata khuluq, yang berarti budi pekerti, tingkah laku, atau tabiat. Berakar dari kata khalaqa yang berarti menciptakan. Seakar dengan kata khaliq (pencipta), makhluq (yang diciptakan) dan khalaq (penciptaan). Kesamaan akar kata diatas mengisyaratkan bahwa dalam akhlak tercangkup pengertian keterkaitannya antara tuhan dan makhluk. Maka akhlak dapat diartikan sebagai suatu tata aturan atau norma prilaku yang mengatur hubungan keterkaitan antara manusia, manusia dengan tuhan bahkan dengan alam semesta. ${ }^{1}$

Secara terminologi, akhlak didefinisikan oleh para ulama dan tokoh pendidikan dalam bentuk yang sangat beragam diantaranya sebagai berikut:

\section{a. Imam Al-Ghazali mendefinisikan} bahwa akhlak adalah

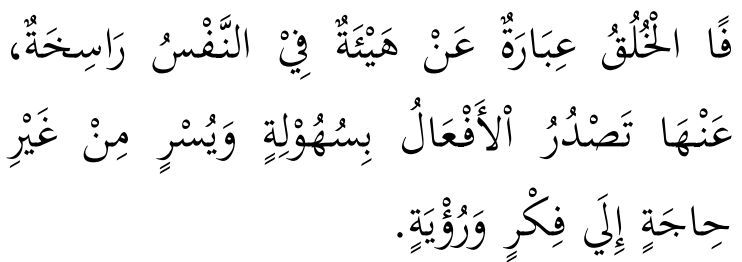

"Akhlak adalah sifat yang tertanam dalam jiwa yang menimbulkan perbuatanperbuatan dengan gampang dan mudah, tanpa memerlukan pemikiran dan pertimbangan."

\section{b. Ibrahim Anis mendefinisikan bahwa akhlak adalah}

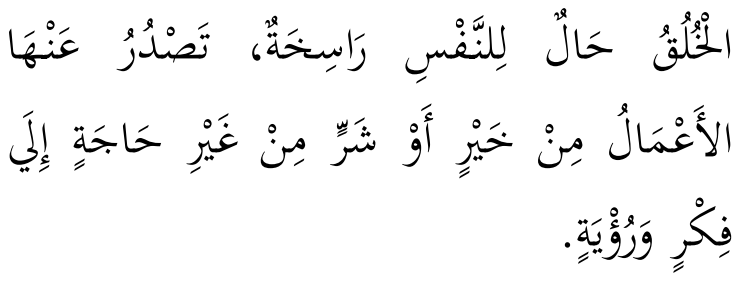

${ }^{1}$ Yunahar Ilyas, Kuliah Akhlaq, (Yogyakarta: Lembaga Pengkajian Dan Pengalaman Islam, 2002), h. vii
"Akhlak adalah sifat yng tertanam dalam jiwa, yang dengannya lahirlah macammacam perbuatan, baik atau buruk, tanpa membutuhkan pemikiran dan pertimbangan." 2

\section{c. Ibnu Maskawaih mendefinisikan bahwa akhlak adalah}

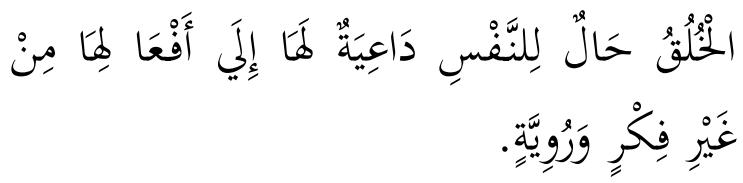

"Akhlak adalah keadaan gerak jiwa yang mendorong ke arah melakukaan perbuatan dengan tidak mengahajatkan pikiran. "3

Definisi tersebut dapat dipahami bahwa akhlak adalah sifat yang tertanam dalam jiwa seseorang, yang mengakibatkan seseorang tersebut melakukan perbuatan baik atau buruk, dengan mudah tanpa adanya pemikiran panjang atau secara spontan. Muhammad Abdullah Draz membagi ruang lingkup akhlak kepada liama bagian sebgai berikut;

1). Akhlak pribadi (al-akhlak al-afrdiyah) terdiri dari; yang diperintahkan (alAwamir), yang dilarang (an-nawhu) yang di bolehka (al-mubahat) dan akhlaq dalam keadaan daruarat (almukhalafah bi al-idhthirah).

2). Akhlak berkeluarga (al-akhlak usuruyah) terdiri dari kewajiban tinggal balik orang tua dan anak, kewajiban suami isatri, dan kewajiban terhadap karib kerabat.

3). Akhlak bermasyarakat (al-akhlak ijtimaiyah) terdidir dari yang dilarang, yang diperintahkan dan kaedah-kaedah adab.

4). Akhlak bernegara (al-akhlak addaulah) terdiri dari, hubungan antara

${ }^{2}$ Yunahar Ilyas, Kuliah Akhlaq, (Yogyakarta: Lembaga Pengkajian Dan Pengalaman Islam, 2002), h. vii

${ }^{3}$ Rachmat Djatnika, Sistem Ethika Islami, (Jakarta: Pustaka Panjimas, 1992), h. 26-27. 
pemimpin dan rakyat dan hubungan luar negri.

5). Akhlak beragama (al-akhlak addiniyah) yaitu kewajiban terhadap Allah SWT.

Sistematika ruang lingkup akhlak yang dirumuska oleh Abu Draz tampak bahwa ruang lingkup akhlak sangat luas mencangkup seluruh aspek kehidupan, baik sedar vertikal maupaun horizintal. Dari sitematika tersebut dapar dipahami bahwa ruang lingkup akhlam meliputi, akhlak teradapa Allah SWT, terhadapa Rasulallah SAW, akhlak pribadi, dalam keluarga, bermasyarakat, serta akhlak bernegara. ${ }^{4}$ Maka pendidikan akhlak dapat dipahami sebagai suatu rangkaian proses pengintegrasian nilai-nilai kepribadian luhur terhadap peserta didik. Sebagai bekal kemampuan peserta didik dalam menempuh kehidupan sosial yang baik.

\section{Pendidikan Integratif-Inklusif}

Secara bahasa integratif berasal dari bahasa inggris yaitu integrate yang berarti penyatuan. Sedangkan secara istilah dapat dirtikan sebagai suatu proses menjadikan satu (penyatuan). Integrasi dalam istilah psikologi yang diartikan sebagai sebuah proses penyatuan serangkaian peristiwa atau sistem-sistem yang berbeda menjadi suatu kebulatan yang sifatnya utuh atau sebuah upaya guna menghimpun suatu hubungan yang berarti atau relasi-relasi tertentu atau menunjuk pada adanya proses pengkoordinasian. Sedangkan secara umum integrasi diartikan sebagai penyatuan secara terencana dari bagianbagian yang berbeda-beda menjadi satu kesatuan yang serasi. Menurut pandangan Assegaf, integratif pada mata pelajaran pendidikan agama islam memiliki makan bahwa keterpaduan kebenaran wahyu (burhan qauli) dengan bukti bukti yang ditemukan di alam semesta (burhan kauni).

\footnotetext{
${ }^{4}$ Yunahar Ilyas, Kuliah Akhlaq. h. 6.
}

Keterpaduan yang dimaksud antara ayat alqur'an atau hadis dengan kejadian yang dialami secara rasional atau dalam kehidupan sehari-hari. ${ }^{5}$

Dikatakan struktur keilmuan integratif bukan berarti antara berbagai ilmu tersebut dilebur menjadi satu bentuk ilmu yang identik, melainkan karakter, corak, dan hakikat antara ilmu tersebut terpadu dalam kesatuan dimensi material spiritual, akal-wahyu, ilmu umum ilmu agama, jasmani-ruhani, dan dunia akhirat. Sedangkan interkoneksitas adalah keterkaitan satu pengetahuan dengan pengetahuan yang lain akibat adanya hubungan yang saling mempengaruhi. Integrasi menghendaki adanya hubungan atau penyatuan atau sinkronisasi atau saling menyapa atau kesejajaran antar tiap bidang keilmuan yang ada. Setiap bidang keilmuan tidak dapat berdiri sendiri, tanpa saling menyapa dengan bidang keilmuan yang lain. Keadaan saling menyapa ini, dapat muncul secara induktif, integral (menyatu dalam bahasan), dapat juga dalam bahasan yang komprehensif (kelengkapan aspek tinjauannya), interdisipliner dalam artian dari berbagai tinjauan, holistik (tinjauan menyeluruh) dan tematik (pembahasan sesuai dengan tema). ${ }^{6}$

Secara etimologis inklusif memiliki arti terhitung, global, menyeluruh, penuh, dan komprehensif. Kata inklusif berasal dari bentukan kata bahasa inggris inclusive yang artinya termasuk di dalamnya. Sedangkan secara istilah inklusif, merupakan suatu hal yang berkaitan

\footnotetext{
${ }^{5}$ Siti Mutma'inah, Pendekatan Integratif: Tinjauan Paradigmatif Dan Implementatif Dalam Pembelajaran Fikih Di Madrasah Ibtidaiyah, Dalam Jurnal Elementari Vol. 5 / No. 2 / JuliDesember 2017, h. 435.

${ }^{6}$ Siti Mutma'inah, Pendekatan Integratif: Tinjauan Paradigmatif Dan Implementatif Dalam Pembelajaran Fikih Di Madrasah Ibtidaiyah, Dalam Jurnal Elementari Vol. 5 / No. 2 / JuliDesember 2017, h. 435.
} 
dengan banyak aspek hidup manusia yang didasarkan atas prinsip persamaan, keadilan, dan hak individu. ${ }^{7}$ Dalam pradigman pendidikan inklusif pesetata didik dilihat sebagai mahluk hidup yang sama tidak terbedakan oleh sekat dikotomi strata sosial, budaya, serta kemamapuan daya fikir dan kemapuan aggota fisik.

Maka pendidikan integratif-inklusif memiliki makna bahwa suatu proses pendidikan harus mencangkup ruang lingkup yang luas dan menyeluruh. Pendidikan akhlah secara integratifinklusif memiliki cangkupan ruang lingkup yang menyeluruh dan holistik. Pendidikan akhlak tidak memisahkan diri dari mata pelajaran yang lain serta memperhatikan kemamapuan peserta didik dalam melakukan proses pembelajaran.

\section{Implikasi Pendidikan Integrasi-inklusif}

Pendidikan Integrasi-inklusif tersebut dapat berangkat dari rancangan skenario pembelajaran, pelaksanaan pembelajaran, hingga evaluasi pembelajaran. Pembelajaran dengan berwawasan keilmuan integratif, menjadikan proses pembelajaran yang disampaikan oleh guru maupun dosen terjaga keutuhanya, dan tidak saling memisahkan antara satu ilmu dengan ilmu yang lain. Pendidikan tidak lagi sekedar normatif tapi juga saintifik. Pemahaman yang ditimbulkan dari Pembelajaran integratif akan menggiring peserta didik pada belajar secara totalitas, dan menjadikan matri pendidikan sebagai bagian dari kehidupan nyata (real life) yang dibutuhkan oleh mereka. ${ }^{8}$

${ }^{7}$ Nasri Kurnialoh, Pendidikan Agama Islam Berwawasan Inklusif-Pluralis, Dalam Jurnal Insania Vol. 186, No. 03, September-Desember, h. 391.

${ }^{8}$ Siti Mutma'inah, Pendekatan Integratif: Tinjauan Paradigmatif Dan Implementatif Dalam Pembelajaran Fikih Di Madrasah Ibtidaiyah, h. 437.
Adapun proses pengintegrasian dapat dilakukan dengan model sebagiai berikut:

\section{a. Integrasi tingkat filosofis}

Tingkat filosofis dalam integrasi sains-sosial dalam pembelajaran PAI dimaksudkan bahwa setiap kajian harus diberi nilai fundamental dalam kaitannya dengan disiplin keilmuan lainnya dan dalam hubungannya dengan nilai-nilai humanistik. Seperti mengajar materi Akhlak, di samping makna fundamentalnya sebagai filosofi membangun hubungan antar manusia, alam, dan Tuhan dalam ajaran Islam, dalam pengajaran Akhlak harus juga ditanamkan pada peserta didik bahwa eksistensi Akhlak tidaklah berdiri sendiri, melainkan berkembang bersama disiplin keilmuan yang lainnya seperti falsafah, sosiolgi, psikologi, dan lain sebagainya.

\section{b. Integrasi tingkat metode dan pendekatan riset}

Yang dimaksud dengan metodologi di sini adalah metodologi yang digunakan dalam pengembangan ilmu bersangkutan (PAI). Dalam pengertian yang lebih luas berupa pendekatan (approach). Misalkan dalam perkuliahan Ilmu Pendidikan Islam (IPI), metodologi dan pendekatan yang digunakan adalah pengalaman empiris mahasiswa selama studi dengan jalan mengamati kegiatan lembaga pendidikan Islam. Sedangkan matakuliah Filsafat Pendidikan Islam (FPI) menerapkan pola berpikir deduktif, yang berangkat dari kebenaran yang ada dalam Islam, kemudian dilihat dari fenomena-fenomena yang ada dalam masyarakat. Juga pola berpikir induktif, artinya berbagai kasuskasus pendidikan ditarik hubungannya dengan norma-norma yang ada di dalam Islam.

\section{c. Integrasi tingkat materi}

Tingkat materi merupakan suatu proses bagaimana mengintegrasikan nilai- 
nilai kebenaran universal umumnya dengan kajian keislaman khsususnya ke dalam sains-sosial seperti fisika, kimia, biologi, sosiologi, antropologi, hukum, politik, ekonomi, pendidikan, dan sebagainya. Sebaliknya, mempertemukan ilmu-ilmu umum tersebut ke dalam kajian keislaman, dengan jalan memadukannya melalui epistimologi dan aksiologi. Sebagai contoh, untuk mengajarkan tema Akhlak perlu menyajikan buku-buku secara integratif dengan jalan mempertemukan berbagai teori yang ada dalam kajian keislaman dengan teori-teori modern.

Integrasi pada tingkat materi dapat dilakukan dengan salah satu dari beberapa pendekatan, intradisipliner, multidisipliner, interdisipliner, dan transdisipliner. Integrasi Intradisipliner yaitu mengintegrasikan kompetensi-kompetensi sikap, pengetahuan dan keterampilan menjadi satu kesatuan utuh pada setiap mata pelajaran. Pendekatan ini dilakukan dengan merumuskan keempat kelompok kompetensi dasar. Integrasi multidisipliner dan interdisipliner dilakukan dengan membuat berbagai mata pelajaran saling berkaitan satu sama lain agar saling memperkuat, menghindari tumpang tindih dan dapat menjaga keselarasan setiap mata pelajaran. Integrasi multidisipliner dilakukan tanpa menggabungkan kompetensi dasar setiap mata pelajaran, sedangkan integrasi interdisipliner dilakukan dengan menggabungkan kompetensi-kompetensi dasar dari beberapa mata pelajaran menjadi satu. Integrasi transdisipliner yaitu dengan mengaitkan berbagai mata pelajaran yang ada dengan permasalahan permasalahan yang dijumpai di sekitarnya, sehingga pembelajaran menjadi kontekstual. ${ }^{9}$

\footnotetext{
${ }^{9}$ Siti Mutma'inah, Pendekatan Integratif: Tinjauan Paradigmatif Dan Implementatif Dalam Pembelajaran Fikih Di Madrasah Ibtidaiyah, h. 438.
}

\section{d. Integrasi tingkat strategi}

Jika tingkat materi menunjukan pada bahan yang disedianya akan disampaikan dalam proses pembelajaran, maka tingkat strategi merupakan tahapan pelaksanaan pembelajaran dengan menerapkan berbagai model dan metode pembelajaran. Pembelajaran dengan model active learning dengan turunan berbagai macam metode, teknik, dan taktik pembelajaran adalah perlu dipilih dan dipraktekkan oleh guru-dosen pada saat proses pembelajaran berlangsung. Jika guru-dosen menghadapi keterbatasan dan kelemanahan dalam pelaksanaannya, maka dapat dibentuk team teaching dengan guru-dosen lintas bidang keilmuan, agar terjadi pembelajaran integratif. Semakin banyak disiplin keilmuan yang diintegrasikan dalam suatu pembelajaran, semakin membutuhkan strategi pembelajaran yang bervariasi serta melibatkan banyak guru-dosen untuk mengajar bidang ilmu yang dikaji.

\section{e. Integrasi tingkat evaluasi}

Tingkat evaluasi dilakukan setelah seluruh proses pembelajaran PAI selesai, agar diketahui berapa besar keberhasialan dan kegagalan, keunggulan dan kelemahan, serta bagian mana yang perlu remedial. Tingkat evaluasi tidak bias diabaikan kerena proses pembelajaran tidak dapat diketahui hasilnya tanpa evaluasi. Evaluasi pendidikan secara singkat dimaknai sebagai kegiatan menilai yang terjadi dalam proses pendidikan. Pembelajaran PAI pada akhirnya perlu dievaluasi untuk mengukur ketercapaian tujuan dari pembelajaran itu sendiri. ${ }^{10}$

Kelima tingkat integrasi tersebut harus dilakukan secara simultan dan sinergis agar tiap level juga mengalami

\footnotetext{
${ }^{10}$ Siti Mutma'inah, Pendekatan Integratif: Tinjauan Paradigmatif Dan Implementatif Dalam Pembelajaran Fikih Di Madrasah Ibtidaiyah, h. 444.
} 
keterpaduan. Pada prinsipnya dari penjabaran di atas, integrasi keilmuan dapat dan harus dilakukan pada semua pembelajaran universal, pembelajaran Akhlak dikaitkan dengan sains-sosial atau sebaliknya pembelajaran sains-sosial yang berintegrasi dengan keilmuan Islam. Sehingga pada akhirnya dikotomi keilmuan yang cenderung dapat merusak keseimbangan peradaban bisa dihindarkan.

\section{Materi Akhlak Berwawasan Integrasi- Inklusif}

Model pengintegrasian pendidikan akhlak pada tingkat materi sebagai suatu cara dalam melakukan proses pendidikan akhlak dengan tidak terbatasi oleh bidang studi pendidikan akan tetapi mencakup bidang studi secara keseluruhan, bahkan mencakup seluruh program pendidikan secara integratif. Hasil rumusan Kemendiknas dan Kemenag menyimpulkan bahwa pendidikan budi pekerti (akhlak) bukan merupakan mata pelajaran tersendiri (monolitik), tetapi merupakan program pendidikan terpadu yang memerlukan prilaku, keteladanan, pembiasaan, bimbingan dan penciptaan lingkungan moralitas yang kondusif. Pendidikan akhlak dapat menjadi soft skill (dampak pengiring) bagi setiap mata pelajaran. Hal ini bisa dilakukan, antara lain dengan memasukkan character-based approach sebagai upaya membangun karakter peserta didik yang berbudi luhur secara bersama-sama. Inilah bentuk upaya mengupayakan proses pendidikan akhlak secara integratif yang menjadi bagian penting dari pengembangan kurikulum 2004 yang bercorak KBK (Kurikulum Berbasis Kompetensi) menjadi KTSP (Kurikulum Tingkat Satuan Pendidikan) pada 2006 dan menjadi tugas penting bagi sekolah atau Sekolah untuk melakukan improvisasi guna meningkatkan mutu pendidikan, terutama dalam menanamkan dan membentuk kebiasaan berakhlak mulia bagi peserta didik. Pada tahun 2013 disempurnakan dengan kurikulum yang mengintegrasikan pendidikan karakter dalam setiap mata pelajaran. ${ }^{11}$

Integrasi pada tingkat materi merupakan suatu proses bagaimana mengintegrasikan nilai-nilai kebenaran universal umumnya dengan kajian keislaman khsususnya ke dalam sainssosial seperti fisika, kimia, biologi, sosiologi, antropologi, hukum, politik, ekonomi, pendidikan, dan sebagainya. Sebaliknya, mempertemukan ilmu-ilmu umum tersebut ke dalam kajian keislaman, dengan jalan memadukannya melalui epistimologi dan aksiologi. Sebagai contoh, untuk mengajarkan tema Akhlak perlu menyajikan buku-buku secara integratif dengan jalan mempertemukan berbagai teori yang ada dalam kajian keislaman dengan teori-teori modern. Integrasi pada tingkat materi dapat dilakukan dengan salah satu dari beberapa pendekatan, intradisipliner, multidisipliner, interdisipliner, dan transdisipliner sebagai berikut:

a. Integrasi Intradisipliner yaitu mengintegrasikan kompetensikompetensi sikap, pengetahuan dan keterampilan menjadi satu kesatuan utuh pada setiap mata pelajaran. Pendekatan ini dilakukan dengan merumuskan keempat kelompok kompetensi dasar.

b. Integrasi Multidisipliner Dan Interdisipliner dilakukan dengan membuat berbagai mata pelajaran saling berkaitan satu sama lain agar saling memperkuat, menghindari tumpang tindih dan dapat menjaga keselarasan setiap mata pelajaran. Integrasi multidisipliner dilakukan tanpa menggabungkan kompetensi

\footnotetext{
${ }^{11}$ Ahmad Royani, Pendidikan Akhlak Aplikatif Integratif Di Sekolah, Dalam Jurnal Fenomena, Vol. 14 No. 1 April 2015, h. 152.
} 
dasar setiap mata pelajaran, sedangkan integrasi interdisipliner dilakukan dengan menggabungkan kompetensikompetensi dasar dari beberapa mata pelajaran menjadi satu.

c. Integrasi Transdisipliner yaitu dengan mengaitkan berbagai mata pelajaran yang ada dengan permasalahan permasalahan yang dijumpai di sekitarnya, sehingga pembelajaran menjadi kontekstual. ${ }^{12}$

\section{Pembelajaran Materi Akhlak Birrul Walidain Kelas XI Berwawasan Integratif-Inklusif \\ Imam adz-dzahabi menjelaskan,} bahwa birrul walidain atau bakti kepada orang tua, hanya dapat direalisasikan dengan memenuhi tiga bentuk kewajiban yaitu, mentaati segala perintah orang tua, kecuali maksiat, menjaga amanah harta yang dititipkan orang tua, atau diberikan oleh orang tua dan membantu atau menolong orang tua bila mereka membutuhkan. Materi pendidikan akhlak dengan menggunakan pendekatan Integrasi transdisipliner pada materi akhlak Biruul walidain kelas XI dapat di integratifkan dalam berbagai materi pendidikan sebagai berikut:

\section{a. Membuka Relung Hati}

\section{1) Kisah Uwais Al Qorni}

Merupakan kisah seorang pemuda dari Yaman pada masa Nabi yang sangat berbakti terhadap orang tuanya. Suatu ketia dia meminta izin kepada ibunya untuk bertemu Nabi, namun dia tidak dapat bertemu karena Nabi sedang melaksanakan perang dan dia tidak bisa menunggu Nabi karena tidak bisa meninggalkan ibunya yang sedang sakit. Sampai pada suatu ketika Nabi mencetikan pada para sahabat

\footnotetext{
${ }^{12}$ Siti Mutma'inah, Pendekatan Integratif: Tinjauan Paradigmatif Dan Implementatif Dalam Pembelajaran Fikih Di Madrasah Ibtidaiyah, h. 438.
}

bahwa dia penghuni langit. Suatu ketika disaat dia meningga terjadi hal yang luar biasa bahwa pada saat dimandikan, dikubur, dan jenazah dimakamkan sudah banyak orang yang melaksanankannya, yang menjadikan rasa tajub orang-orang Yaman.

\section{2) Hadis Keutamaan Orang Tua}

"Dari Aisah r.a ia berkata, "Pernah ada seorang laki-laki datang menemui Rasulallah saw. Bersama orang tua, Nabi bertanya, "siapakah orang yang mengertaimu itu?" Ayahku, jawabnya. Rasulallah berpesan kepadaya, jangan kau berjalan di depannya, jangan kau duduk sebelum dia duduk, jangan kau panggil dengan namanya, dan jangan kau memancing amarahnya." (RH. AthThabari).

"Dari Aisah r.a ia berkata, "Pernah ada seorang laki-laki datang menemui Rasulallah saw. Bersama orang tua, Nabi bertanya, "siapakah orang yang mengertaimu itu?" Ayahku, jawabnya. Rasulallah berpesan kepadaya, jangan kau berjalan di depannya, jangan kau duduk sebelum dia duduk, jangan kau panggil dengan namanya, dan jangan kau memancing amarahnya." (RH. AthThabari).

\section{3) Peran Orang Tua dalam Proses Kejadian Manusia}

Bahwa kedua orangtua memiliki peran yang sangat besar pada kehidupan kita mereka berkontribusi sebagai seseorang yang dititipi oleh Allah secara biologis memiliki andil dalam terciptanya kita. Sebagaimana Q.S Al-Mu'min Ayat 67 sebagai berikut; Dia-lah yang mencipatakan kamu dari tanah kemudian dari setetes mani, sesudahnya itu dari segumpal darah kemudian dilahirkan kau sebgai seorang anak, kemudian (kamu dibiarakan hidup) supaya kamu sapai kepada masa (dewasa), Kemudian (dibiarkan kamu hidup lagi) sapai tua, diantara kamu ada yang diwafatkan 
sebelum itu. (kamiperbuat demikian) supaya kamu sapai kepada ajal yang ditentukan dan sepaya kamu memahami (Nya).

\section{4) Manafaat Dan Kandungan ASI}

ASI eksklusif diberikan sejak bayi lahir ke dunia hingga berusia enam bulan. Selama periode tersebut, disarankan untuk hanya memberikan si kecil ASI, tanpa tambhan asupan apapun. Sebab terdapat banyak manfaat ASI esklusif yang bisa didapat oleh banyi. ASI ibu memiliki kandungan nutrisi yang penting bagi tumbuh kembang bayi, yaitu vitamin, protein, karbohidrat, dan lemak. Kompisisinya pun lebih mudah dicerna ketimbang susu formula. Bahkan ASI tidak hanya bermanfaat bagi banyi namun juga bagi ibu.

a) Sebagai Asupan Untuk Menambah Kekebalan Bayi. ASI mengandug zat antibodi pembentuk kekebalan tubuh yang bisa membantunya melawan bakteri dan virus. Maka bayi yang diberi ASI akan beresiko kecil untuk terserang penyakit, diare, asma, alergi, infeksi telinga, infeksi saluran pernafasan, konstipasi, sindrom kematian bayi mendada, dan meningitis. Dayi yang diberikann ASI juga beresiko lebih rendah untuk mengalami obesitas dan diabetes tipe 2 dikemudian hari.

b) Menambah Kecerdasan Bayi. Menurut para ahli asam lemak yang terdapat pada ASI memiliki peranan penting bagi kecerdasan otak bayi dan membentuk hubungan emosional yang positif.

c) Berat Badan Ideal. Bahwa para ahli ASI lebih sedikit merangsang produksi insulin ketimbang susu formula. Hormon insulin merupakan hormon yang memicu pemebentukan lemak serta ASI memiliki kadar leptin lebih tinggi yaitu hormon yang menimbulkan rasa kenyang dan dalm metabolisme lemak.

d) Tulang Bayi Lebih Kuat. Pemeberian ASI selam tiga bulan atau lebih akan membentuk tulang leher dan tulang belakang yang kuat. Mendaptakan limbahan kolestrol kolestrol pada orang dewasa merupakan asupan yang tidak baik namun berbeda dengan bayi, kolestrol sangat dibutuhkan banyi guna menunjang pertumbuhan dan perkembangan

e) Mngurangi Rusiko Terjadinya Sindrom. Yaitu sindron SIDS merupakan sindrom kematian banyi mendadak.

f) Memperkuat Hubungan Ibu Dan Anak

g) Tumbuh Lebih Langsing

h) Mengurangi Stres

i) Mengurangi Pendarahan

j) Resiko Terkena Kanker Menurun

k) Semakin lama menyusui semakin anda terhindar dari penyakit kanker payudara dan ovarium karena terjadi penekanan produksi Hormon estogen. ${ }^{13}$

\section{b. Memperkaya Khazanah}

1) Terdapat Hubungan Batin

Terdapat ikatan batin antara ibu dan anak, hal tersebut terbentuk semasa anak lahir. Menurut suatu penelitian bahwa menjelaskan bagaimana pembentukan ikatan batin antara anak dan ibu dipengaruhi oleh dopamin atau yang dikenal dengan hormon kebahagiaan yang diproduksi oleh tubuh. Para peneliti sepakat bahwa dopamin sebagai penguat ikatan batin antara ibu dan anak. waktu yang diperlukan dalam menjalin ikatan batin kurang lebih selama satu tahun. Setiap banyi yang lahir sudah dapat mulai beradaptasi dengan lingkungan barunya. Ikatan batin akan diperkuat dengan

\footnotetext{
${ }^{13} \mathrm{https} / /$ : www.aladokter.com/13-manfaatmemberikan-asi-eksklusif.html di akses pada 20 November 2019 pada jam 01.00.
} 
pemberiian ASI ibu terhadap bayi. Bahkan sebuah penelitian menjelaskan bahwa hormon oksitosin yang diproduksi ibu ketika menyusui mampu menguatkan ikatan antara ibu dan anak. bayi juga akan secara alami membentuk ikatan batin dengan ibunya ketika menangis, tersenyum, dan kontak mata pada saat menyususi. Ikatan batin ibu juga dapat tebentuk lewat kesehariian seorang anak dengan ibunya. Serta hubungan batin tersebut juga masih bisa dirasaakn ketika sudah beranjak dewasa. ${ }^{14}$

\section{2) Dilapangkan Rizki Dan Umur Panjang}

Hadis Keridhaan Allah Terletak Pada Ridho Orang Tua, terdapat keterkaitan antara bungan hamlum minalloh dan minnanas. Yaitu kebaikan yang kita berikan kepada orang tua akan berdampak pada diri kita begitu juga keburukan. Maka dalam hadis lain dijelaskan birrul walidain akan memudahhkan jalan rizki dan umur panjang. Diantaranya zirki sangat dipengaruhi kebaikan lewat orang disekitar kita dan umur, kebahgiaan, cara hidup sehat, dapat juga demikian serta pemberian langsug.

\section{Hakikat Pendidikan Akhlak Berwawasan Integratif-Inklusif}

Pendidikan akhlak integratif tidak cukup hanya dengan meletakkan dasar kebaikan perilaku dalam seluruh bidang studi dan menjadikannya sebagai satu kesatuan sistematis dalam membangun karakter peserta didik. Tidak cukup pula menciptakan lingkungan yang dapat menumbuhkan budi pekerti luhur hanya di sekolah, tetapi juga harus menciptakan lingkungan akhlak mulia ini terutama di lingkungan keluarga dan masyarakat, sehingga pendidikan akhlak integratif yang

\footnotetext{
${ }^{14} \mathrm{https//:www.hellosehat.com/kehamilan/per}$ kembangan/-janin/ikatan-batin-ibu-anak/ di akses pada 20 November 2019 pada jam 01.00 .
}

melibatkan semua pihak menjadi tanggung jawab bersama antara sekolah, keluarga dan masyarakat. Berikut skema pembelajaran pendidikan akhlak aplikatif intergratif merupakan model pendidikan ahlak yang terintegrasi kedalam seluruh rangkian proses pendidikan akhlak. Dimana dalam hal ini Pendidik di anjurkan untuk menanamkan nilai pendidikan akhlak/moral kepada siswa.

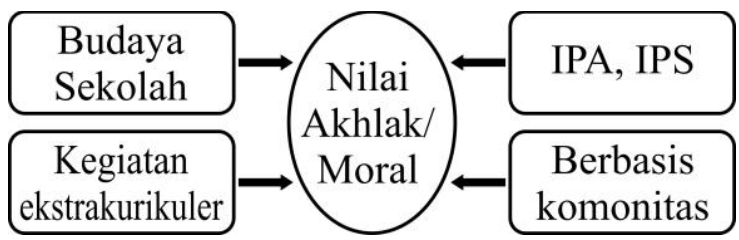

Amirulloh Syarbini dalam bukunya yang berjudul "pendidikan karakter: panduan lengkap mendidik karakter anak di sekolah, Sekolah dan rumah" membagi desain pendidikan akhlak/pengembangan karakter disekolah menjadi empat desain diantaranya yaitu:

Pertama, mengintegrasikan ke setiap mata pelajaran. Mengintegrasikan ke setiap mata pelajaran tujuan untuk memperkenalkan nilai-nilai akhlak disetiap mata pelajaran, sehingga menyadari akan pentingnya nilai tersebut. Nilai-nilai tersebut dicantumkan dalam silabus dan RPP. Pengembangan nilai-nilai itu dalam silabus ditempuh melalui cara-cara berikut ini:

a. Mengkaji Standar Komptensi (SK) dan Kompetensi Dasar (KD) pada Standar Isi (SI) untuk menentukan apakah nilainilai akhlak sudah tercakup di dalamnya

b. Menggunakan yang memperlihatkan keterkaitan antara SK dan KD dengan nilai dan indikator untuk menentukan nilai yang akan dikembangkan

c. Mencantumkankan nilai-nilai akhlak dalam silabus;

d. Mencantumkan nilai-nilai yang sudah tertera dalam silabus ke dalam RPP 
e. Mengembangkan proses pembelajaran peserta didik secara aktif yang memungkinkan peserta didik memiliki kesempatan melakukan internalisasi nilai dan menunjukkannya dalam perilaku yang sesuai; dan memberikan bantuan kepada peserta didik, baik yang mengalami kesulitan untuk menginternalisasi nilai maupun untuk menunjukkannya dalam perilaku.

Kedua, Pengembangan budaya sekolah maksudnya yang membentuk akhlak siswa adalah pranata sosial sekolah kerena merekalah yang lebih tau nilai-nilai apa yang harus dimiliki oleh pesrta didik agar menjadi manusia yang berakhlak. Budaya sekolah cakupannya sangat luas, umumnya men-cakup ritual, harapan, hubungan, demografi, kegiatan kurikuler, kegiatan ekstrakurikuler, proses mengambil keputusan, kebijakan maupun interaksi sosial antarkomponen di sekolah. Budaya sekolah adalah suasana kehidupan sekolah tempat peserta didik berinteraksi dengan sesamanya, Pendidik dengan Pendidik, konselor dengan sesamanya, pegawai administrasi dengan sesamanya, dan antaranggota kelompok masyarakat sekolah. Interaksi internal kelompok dan antarkelompok terikat oleh berbagai aturan, norma, moral serta etika bersama yang berlaku di suatu sekolah. Kepemimpinan, keteladanan, keramahan, toleransi, kerja keras, disiplin, kepedulian sosial, kepedulian lingkungan, rasa kebangsaan, dan tanggung jawab merupakan nilai-nilai yang dikembangkan dalam budaya sekolah. Pengembangan nilai-nilai dalam pendidikan budaya dan karakter bangsa dalam budaya sekolah mencakup kegiatan-kegiatan yang dilakukan kepala sekolah, Pendidik, konselor, tenaga administrasi ketika berkomunikasi dengan peserta didik dan menggunakan fasilitas sekolah

$$
\text { Ketiga, melalui kegiatan }
$$
ekstrakurikuler, kegiatan ekstrakurikuler merupakan kegiatan sekolah yang ada diluar mata pelajaran yang bertujuan untuk membentuk kreatuvitas siswa untuk bisa menyalurkan bakat, minat dalam rangka mendukung kemandirian siswa.

Keempat, desain berbasis komonitas dimana sekolah melibatkan orang tua dan masayarakat dalam membentuk akhlak peserta didik. Ki Hajar Dewantara menyebutkan pola kerjasama antara keluarga, masyarakat, dan sekolah (tripusat pendidikan) dalam membentuk budipekerti sangat dibutuhkan oleh karena itu peran ketiganya tidak bisa dipisahkan. Pendidikan memiliki peranan yang sangat besar dalam membentuk kepribadian setiap manusia. Pendidikan merupakan proses pengembangan potensi peserta didik sehingga menjadi pribadi yang paripurna (insan kamil). Salah satu indikator insan kamil tersebut adalah setiap peserta didik melahirkan akhlaq al-karimah. Sebagaimana yang dikemukakan oleh Ki Hajar Dewantara, bahwa ada tiga lembaga pendidikan yang turut berperan dalam mengembangkan potensi tersebut, yaitu pendidikan formal, informal dan non formal. Pendidikan formal diwakili oleh sekolah, pendidikan informal diwakili oleh keluarga dan pendidikan non formal dilakukan oleh masyarakat. ${ }^{15}$ Dengan demikian proses pendidikan akhlak secara integratif-inklusif tidak selesai hanya pada batas mata pelajaran di sekolah namun seluruh rangkain proses pendidikan formal, nonformal serta informal turut serta melaksanaakan perannya sebagai lingkungan yang sangat berpengaruh dalam mengembangkan kemampuan kognitif, afektif dan psikomotorik peserta dididk.

${ }^{15}$ Ahmad Royani, Pendidikan Akhlak Aplikatif Integratif Di Sekolah, Dalam Jurnal Fenomena, Vol. 14 No. 1 April 2015,h. 154. 


\section{Simpulan}

Pendidikan akhlak berwawasan integratif-inklusif dapat dimaknai sebagai suatu rumusan proses pendidikan akhlak yang dilakukan secara luas dan holistik. Materi pendidikan akhlak dapat bersinergi dengan seluruh mata pelajaran, dapat bersinergi dengan budaya sekolah, kegitan estrakulikuler serta bersinergi dengan komunitas.

Pertama, mengintegrasikan ke setiap mata pelajaran bertujuan untuk memperkenalkan nilai-nilai akhlak disetiap mata pelajaran, sehingga menyadari akan pentingnya nilai tersebut. Nilai-nilai tersebut dicantumkan dalam silabus dan RPP. Integrasi pada tingkat materi ini dapat dilakukan melalui empat pendekatan yaitu, pendekatan intradisipliner, multidisipliner, interdisipliner, dan transdisipliner.

Kedua, Pengembangan budaya sekolah maksudnya yang membentuk akhlak siswa adalah pranata sosial sekolah kerena merekalah yang lebih tau nilai-nilai apa yang harus dimiliki oleh pesrta didik agar menjadi manusia yang berakhlak. Budaya sekolah cakupannya sangat luas, umumnya men-cakup ritual, harapan, hubungan, demografi, kegiatan kurikuler, kegiatan ekstrakurikuler, proses mengambil keputusan, kebijakan maupun interaksi sosial antarkomponen di sekolah.

Ketiga, melalui kegiatan ekstrakurikuler, kegiatan ekstrakurikuler merupakan kegiatan sekolah yang ada diluar mata pelajaran yang bertujuan untuk membentuk kreatuvitas siswa untuk bisa menyalurkan bakat, minat dalam rangka mendukung kemandirian siswa. Keempat, desain berbasis komonitas dimana sekolah melibatkan orang tua dan masayarakat dalam membentuk akhlak peserta didik menjadi pribadi yang paripurna (insan kamil).

\section{DAFTAR PUSTAKA}

Rachmat Djatnika, Sistem Ethika Islami, (Jakarta: Pustaka Panjimas, 1992)

Yunahar Ilyas, Kuliah Akhlaq, (Yogyakarta: Lembaga Pengkajian Dan Pengalaman Islam, 2002)

Ahmad Royani, Pendidikan Akhlak Aplikatif Integratif Di Sekolah, Dalam Jurnal Fenomena, Vol. 14 No. 1 April 2015

Nasri Kurnialoh, Pendidikan Agama Islam Berwawasan Inklusif-Pluralis, Dalam Jurnal Insania Vol.186, No. 03, September-Desember,

Siti Mutma'inah, Pendekatan Integratif:Tinjauan Paradigmatif Dan Implementatif Dalam Pembelajaran Fikih Di Madrasah Ibtidaiyah, Dalam Jurnal Elementari Vol. 5 / No. 2 / Juli-Desember 2017, https//: $\quad$ www.aladokter.com/13-manfaatmemberikan-asi-eksklusif.html di akses pada 20 November 2019 pada jam 01.00.

https//:www.hellosehat.com/kehamilan/per kembangan/-janin/ikatan-batin-ibuanak/di akses pada 20 November 2019 pada jam 01.00. 
Pendidikan Akhlak Berwawasan Integratif Inklusif

Rausyan Fikr. Vol. 16 No. 1 Maret 2020. ISSN. 1979-0074 e-ISSN. 9772580594187 | 62 